\title{
Angiotensin II and $\mathrm{AT}_{1 \mathrm{a}}$ Receptors in the Proximal Tubules of the Kidney: New Roles in Blood Pressure Control and Hypertension
}

\author{
Ana Paula de Oliveira Leite ${ }^{1,2,+}$, Xiao C. Li ${ }^{1,2,+}$, Sarah M. Nwia ${ }^{1,2,+}$, Rumana Hassan ${ }^{1,2}$ and Jia L. Zhuo ${ }^{1,2, *(D)}$ \\ 1 Tulane Hypertension and Renal Center of Excellence, 1430 Tulane Avenue, New Orleans, LA 70112, USA; \\ adeoliveiraleite@tulane.edu (A.P.d.O.L.); xli68@tulane.edu (X.C.L.); snwia@tulane.edu (S.M.N.); \\ rhassan1@tulane.edu (R.H.) \\ 2 Department of Physiology, Tulane University School of Medicine, New Orleans, LA 70112, USA \\ * Correspondence: jzhuo@tulane.edu; Tel.: +1-(504)-988-4363; Fax: +1-(504)-988-2675 \\ + These authors contributed equally to the work.
}

check for

updates

Citation: Leite, A.P.d.O.; Li, X.C.; Nwia, S.M.; Hassan, R.; Zhuo, J.L. Angiotensin II and $\mathrm{AT}_{1 \mathrm{a}}$ Receptors in the Proximal Tubules of the Kidney: New Roles in Blood Pressure Control and Hypertension. Int. J. Mol. Sci. 2022, 23, 2402. https://doi.org/ $10.3390 /$ ijms 23052402

Academic Editor: Christopher

L. Gentile

Received: 19 January 2022

Accepted: 18 February 2022

Published: 22 February 2022

Publisher's Note: MDPI stays neutral with regard to jurisdictional claims in published maps and institutional affiliations.

Copyright: (c) 2022 by the authors. Licensee MDPI, Basel, Switzerland. This article is an open access article distributed under the terms and conditions of the Creative Commons Attribution (CC BY) license (https:/ / creativecommons.org/licenses/by/ $4.0 /)$.

\begin{abstract}
Contrary to public perception, hypertension remains one of the most important public health problems in the United States, affecting $46 \%$ of adults with increased risk for heart attack, stroke, and kidney diseases. The mechanisms underlying poorly controlled hypertension remain incompletely understood. Recent development in the Cre/LoxP approach to study gain or loss of function of a particular gene has significantly helped advance our new insights into the role of proximal tubule angiotensin II (Ang II) and its $\mathrm{AT}_{1}\left(\mathrm{AT}_{1 \mathrm{a}}\right)$ receptors in basal blood pressure control and the development of Ang II-induced hypertension. This novel approach has provided us and others with an important tool to generate novel mouse models with proximal tubule-specific loss (deletion) or gain of the function (overexpression). The objective of this invited review article is to review and discuss recent findings using novel genetically modifying proximal tubule-specific mouse models. These new studies have consistently demonstrated that deletion of $\mathrm{AT}_{1}\left(\mathrm{AT}_{1 \mathrm{a}}\right)$ receptors or its direct downstream target $\mathrm{Na}^{+} / \mathrm{H}^{+}$exchanger 3 (NHE3) selectively in the proximal tubules of the kidney lowers basal blood pressure, increases the pressure-natriuresis response, and induces natriuretic responses, whereas overexpression of an intracellular Ang II fusion protein or $\mathrm{AT}_{1}\left(\mathrm{AT}_{1 \mathrm{a}}\right)$ receptors selectively in the proximal tubules increases proximal tubule $\mathrm{Na}^{+}$reabsorption, impairs the pressure-natriuresis response, and elevates blood pressure. Furthermore, the development of Ang II-induced hypertension by systemic Ang II infusion or by proximal tubule-specific overexpression of an intracellular Ang II fusion protein was attenuated in mutant mice with proximal tubule-specific deletion of $\mathrm{AT}_{1}\left(\mathrm{AT}_{1 \mathrm{a}}\right)$ receptors or NHE3. Thus, these recent studies provide evidence for and new insights into the important roles of intratubular Ang II via $\mathrm{AT}_{1}\left(\mathrm{AT}_{1 \mathrm{a}}\right)$ receptors and $\mathrm{NHE} 3$ in the proximal tubules in maintaining basal blood pressure homeostasis and the development of Ang II-induced hypertension.
\end{abstract}

Keywords: angiotensin II; $\mathrm{AT}_{1}$ receptor; hypertension; proximal tubule; sex differences

\section{Introduction}

Hypertension affects more than $46 \%$ of adults in the United States, significantly increasing their risk for cardiovascular diseases, stroke, and kidney failure [1-3]. Several classes of drugs are currently available to treat hypertension, including angiotensin-converting enzyme (ACE) inhibitors, angiotensin II (Ang II) receptor blockers (ARBs), calcium channel inhibitors, $\beta$-blockers, and loop diuretics. These antihypertensive drugs act to either inhibit the renin-angiotensin system (RAS), cause blood vessel vasodilatation, induce natriuresis and diuresis, or suppress sympathetic nerve activity [4-7]. Despite widespread treatments with these antihypertensive drugs, only approximately $50 \%$ of patients have attained adequate blood pressure control, while the rest continue to develop apparent 
treatment-resistant hypertension (aTRH) [6]. aTRH has been defined as uncontrolled blood pressure while taking three classes of antihypertensive drugs or taking four classes of antihypertensive drugs regardless of blood pressure control $[4,5,7]$. With nearly $20 \%$ of American adults affected by aTRH, the mechanisms of hypertension, whether controlled or poorly controlled, remain incompletely understood and warrants further studies [4].

The pressure-natriuresis response is one of the major mechanisms by which the kidneys control blood pressure and body salt and fluid homeostasis in response to the changes in renal arterial pressure $[3,4,8]$. A significant increase in arterial blood pressure is expected to trigger the pressure-natriuresis response that, in turn, alters interstitial hydrostatic pressure, proximal tubule $\mathrm{Na}^{+}$transport, and renal medullary blood flow to induce diuresis and natriuresis responses. This is followed by blood pressure returning to control. Conversely, when blood pressure falls significantly, the pressure-natriuresis response is suppressed, antidiuretic and anti-natriuretic responses are augmented, and proximal tubule $\mathrm{Na}^{+}$reabsorption is increased $[3,4,8]$. These responses work together to restore blood pressure back to control. However, how the pressure-natriuresis response is regulated and its potential mediators remain poorly understood. Recent studies suggest that the intratubular RAS, especially Ang II via activation of $\mathrm{AT}_{1}\left(\mathrm{AT}_{1 \mathrm{a}}\right)$ receptors in the proximal tubules of the kidney, plays a key role in basal blood pressure control and the development of Ang II-induced hypertension by regulating proximal tubule $\mathrm{Na}^{+}$reabsorption and the pressure-natriuresis response [9-11].

Recently, the XIII International Symposium on Vasoactive Peptides was held on 15-17 October 2021, which celebrated recent advances in studying the roles of vasoactive peptides, especially the renin-angiotensin system, in cardiovascular, neural, kidney, and blood pressure control, inflammation and the COVID-19 pandemic. Based on a lecture given at this symposium, the objective of this article is to briefly review and discuss recent studies using unique mouse models with proximal tubule-specific deletion (knockout) of Ang II type 1a receptors $\left(\mathrm{AT}_{1 \mathrm{a}}\right.$ ) or its major downstream target protein, the $\mathrm{Na}^{+} / \mathrm{H}^{+}$ exchanger 3 (NHE3) in the kidney [12-16]. These studies have revealed important roles of $\mathrm{AT}_{1 \mathrm{a}}$ receptors, acting alone or via NHE3, in the proximal tubules in maintaining basal blood pressure homeostasis, the pressure-natriuresis response, and the development of Ang II-induced hypertension. This new knowledge improves our understanding of the renal mechanisms of blood pressure regulation as well as Ang II-induced hypertension and suggests that both $\mathrm{AT}_{1 \mathrm{a}}$ receptors and NHE3 may be potential therapeutic targets in treating hypertension in humans.

\section{The Proximal Tubules Are Major Tubular Segments Expressing a Robust Renin-Angiotensin System in the Kidney}

It has long been recognized that the proximal tubules express all major components of the RAS including key enzymes (i.e., renin and $\mathrm{ACE}$ ) and sole substrate (i.e., angiotensinogen) that are required to generate Ang II and the receptors (i.e., $\mathrm{AT}_{1}$ and $\mathrm{AT}_{2}$ ) that mediate the actions of Ang II [17-20]. The proximal tubules also express abundant enzyme (ACE2) and aminopeptidases (i.e., APA and APN) that metabolize Ang II or its downstream active fragments, Ang III or Ang (3-8) [21-24]. Ang II is the most potent effector of all angiotensin peptides and plays the most critical roles in the kidney to regulate blood flow, glomerular filtration, and tubular transport $[13,25,26]$. Most of the well-recognized effects of Ang II in the kidney are mediated by $\mathrm{AT}_{1}$ receptors $[11,13,15,25-29]$, while $\mathrm{AT}_{2}$ receptors play a relatively moderate role in mediating the natriuretic response in the proximal tubules [16,30-33]. The molecular cloning of $\mathrm{AT}_{1}$ and $\mathrm{AT}_{2}$ receptors, and the development of Ang II receptor blockers (ARBs) for treatment of hypertension, diabetic nephropathy, and other kidney diseases represent one of the most significant breakthroughs in the Ang II receptor research field over last 3 decades.

The $\mathrm{AT}_{1}$ receptor is molecularly classified into two subtypes in rodents, $\mathrm{AT}_{1 \mathrm{a}}$ and $\mathrm{AT}_{1 \mathrm{~b}}$, based on their molecular structures [34-37]. However, humans express only one $\mathrm{AT}_{1}$ receptor corresponding to $\mathrm{AT}_{1 \mathrm{a}}$ receptors in rodents. The $\mathrm{AT}_{1 \mathrm{a}}$ receptor was first 
cloned from rat vascular smooth muscle cells with its cDNA encoding a 359 amino-acid protein, a molecular structure typical of seven transmembrane GPCR [36,37]. The $\mathrm{AT}_{1 \mathrm{~b}}$ receptor was subsequently cloned from bovine adrenal cells with its cDNA sharing a $94 \%$ identical amino acid sequence of the $\mathrm{AT}_{1 \mathrm{a}}$ receptor [34,35]. Most $\mathrm{AT}_{1}$ receptors are of the $\mathrm{AT}_{1 \mathrm{a}}$ subtype accounting for $>90 \%$ of the $\mathrm{AT}_{1}$ receptor family in the kidney and other tissues $[25,26,28,38,39]$, whereas the $\mathrm{AT}_{1 \mathrm{~b}}$ receptor accounts for approximately $5-10 \%$, and its expression is mainly confined to the adrenal glands, the kidney, and brain [40-42]. Thus, it is not surprising that most of the well-recognized effects of Ang II are mediated by $\mathrm{AT}_{1 \mathrm{a}}$ receptors, whereas $\mathrm{AT}_{1 \mathrm{~b}}$ receptors play a small role $[13,25,26,28,38]$.

$\mathrm{AT}_{1}$ and $\mathrm{AT}_{2}$ receptors have been localized in the rat, mouse, and human kidney using quantitative in vitro or in vivo autoradiography (Figure 1) [43-48], in situ hybridization histochemistry [49-51], and immunohistochemistry, respectively [52-54]. The localization of $\mathrm{AT}_{1}\left(\mathrm{AT}_{1 \mathrm{a}}\right)$ receptors in the kidney by radioreceptor binding and autoradiography is the gold-standard approach based on the direct GPCR and ligand pharmacology principles [43-48]. This technique has revealed a distinct anatomical distribution or localization of these receptors in the kidneys of rat, mouse, rabbit, monkey, or humans [43-47,55]. Specifically, autoradiographs show a very high density of $\mathrm{AT}_{1}$ receptors in the glomerulus, corresponding to mesangial cells, endothelial cells, and podocytes [43-46]. Although not as high as in the glomerulus, a moderately high level of $\mathrm{AT}_{1}$ receptors is localized in the intervening outer cortex corresponding to proximal convoluted tubules [44-47]. Interestingly, a high density of $\mathrm{AT}_{1}$ receptors is also localized in the longitudinal bands traversing the inner stripe of the outer medulla associated with the vasa recta bundles and type 1 renomedullary interstitial cells $[47,56]$. By contrast, the inner cortex, the outer stripe of the outer medulla, and the entire inner medulla especially toward the tip of the inner medulla express low to undetectable levels of $\mathrm{AT}_{1}$ receptors [43-48]. In comparison, the expression of $\mathrm{AT}_{2}$ receptors is very low throughout the kidney of adult rodents or humans except in the proximal tubules and blood vessels (Figure 1) [47,48]

Other techniques have also been used to localize $\mathrm{AT}_{1}$ and $\mathrm{AT}_{2}$ receptors in the kidney. In situ hybridization histochemistry offers a high sensitivity and specificity to localize $\mathrm{AT}_{1}$ $\left(\mathrm{AT}_{1 \mathrm{a}}\right)$ receptor mRNAs throughout the kidney including the blood vessels, glomerulus, proximal tubules, loop of Henle, distal tubules, and collecting ducts [49-51]. A recent study using the novel RNA scope technique reported similar findings throughout the kidney with $\mathrm{AT}_{1}$ receptor mRNAs observed in mesangial cell, juxtaglomerular cells, proximal tubule cells, interstitial cell, and late afferent and early efferent arterioles [57]. The localization of $\mathrm{AT}_{1}$ and $\mathrm{AT}_{2}$ receptor proteins in the kidney has also been studied, primarily using immunohistochemistry with $\mathrm{AT}_{1}$ and $\mathrm{AT}_{2}$ receptor antibodies [52-54]. The localization of $\mathrm{AT}_{1}\left(\mathrm{AT}_{1 \mathrm{a}}\right)$ and $\mathrm{AT}_{2}$ receptor mRNAs or proteins in most, if not all, kidney cells or structures by these techniques may be different from the localization of $\mathrm{AT}_{1}$ receptor binding sites by radioreceptor or autoradiographic binding [43-48]. Although these techniques are very sensitive to detect $\mathrm{AT}_{1}$ and $\mathrm{AT}_{2}$ receptor mRNAs or proteins in the kidney, the specificity of these approaches, especially using commercially available $\mathrm{AT}_{1}$ or $\mathrm{AT}_{2}$ receptor antibodies for immunohistochemistry, remains controversial [58-60]. 

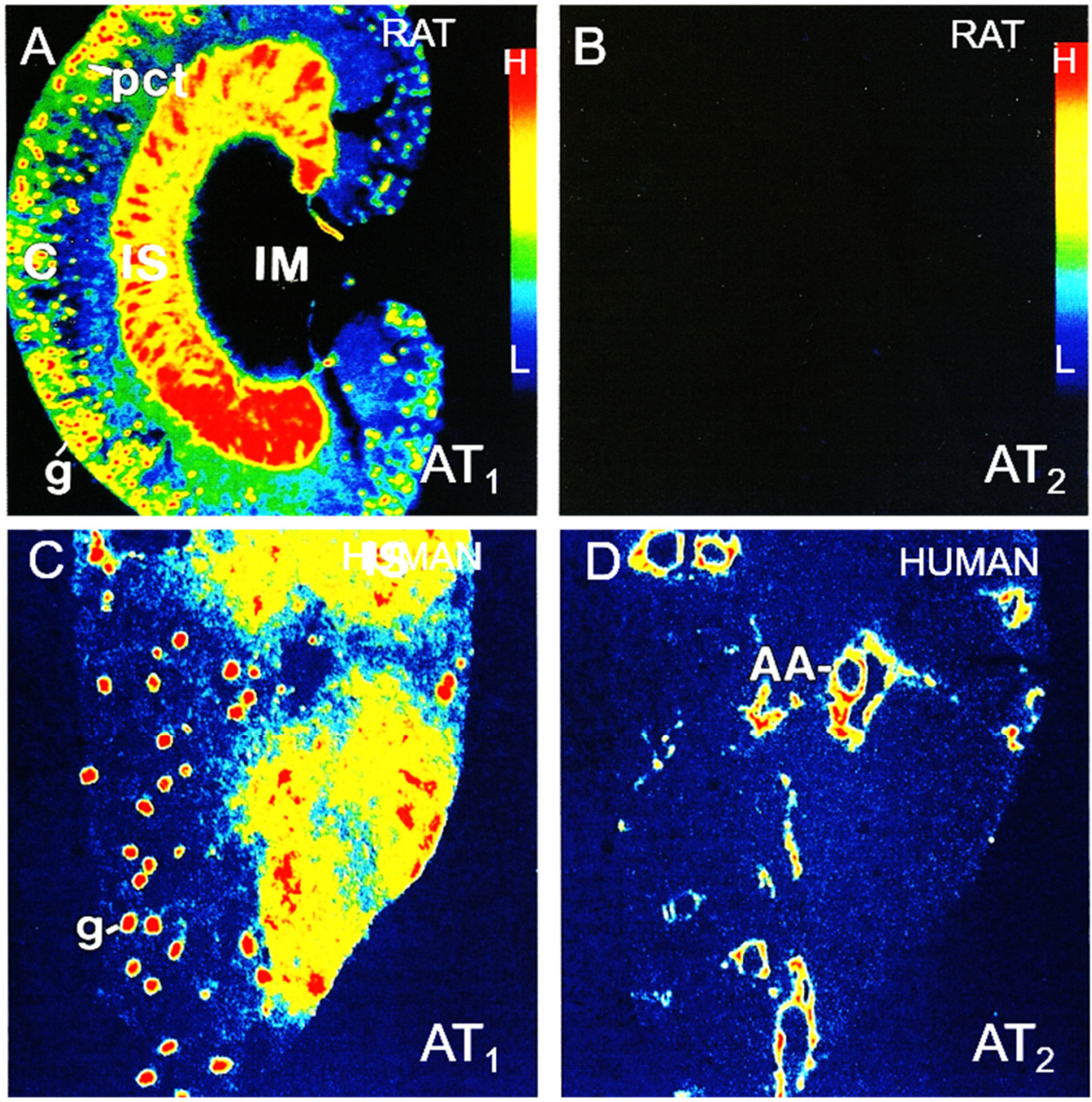

Figure 1. Localization of angiotensin II $\mathrm{AT}_{1}$ and $\mathrm{AT}_{2}$ receptors in the rat $(\mathbf{A}, \mathbf{B})$ and human kidney $(C, D)$ by quantitative in vitro autoradiography using radiolabeled $\left[{ }^{125} \mathrm{I}\right]$-angiotensin $\mathrm{II}$ as a ligand. $\mathrm{AT}_{1}$ receptor binding is defined as $\left[{ }^{125} \mathrm{I}\right]$-angiotensin $\mathrm{II}$ binding in the presence of an excess concentration of unlabeled $\mathrm{AT}_{2}$ receptor blocker PD123319 $(10 \mu \mathrm{M})$, whereas $\mathrm{AT}_{2}$ receptor binding is defined as $\left[{ }^{125} \mathrm{I}\right]$-angiotensin II binding in the presence of an excess concentration of unlabeled $\mathrm{AT}_{1}$ receptor blocker losartan $(10 \mu \mathrm{M})$, respectively. Red represents the highest level of binding, whereas blue represents the background level of binding. C, cortex; IS, inner stripe of the outer medulla; IM, inner medulla; AA, blood vessels including afferent and efferent arterioles and interlobular arteries; g, glomerulus; pct, proximal convoluted tubule. Modified from References [46-48].

\section{The Proximal Tubules Are Major Tubular Segments Expressing the Most Robust NHE3 Abundance in the Kidney, a Major Downstream Target of $\mathrm{AT}_{1}\left(\mathrm{AT}_{1 \mathrm{a}}\right)$ Receptor Activation}

In contrast to the general perception that NHE3 is expressed in every tissue in the body, only two major organs or tissues express NHE3 most abundantly, i.e., the gastrointestinal tract (gut) and the kidney. In the gut, NHE3 is primarily expressed in the small intestines and much less in the stomach and large intestines or colon [61,62]. In the kidney, NHE3 is primarily expressed in proximal convoluted and straight tubules, and to a moderate extent, in the loop of Henle and is virtually not expressed in collecting ducts [61-66]. NHE3 is primarily localized on the apical membranes of the proximal tubules and loop of Henle under physiological conditions and mediates electroneutral $\mathrm{Na}^{+}$entry into the cells from the lumen and $\mathrm{H}^{+}$extrusion from the cells in the proximal tubules [67,68]. After entry into proximal tubule cells, intracellular $\mathrm{Na}^{+}$ions are returned to the blood via the $\mathrm{Na}^{+} / \mathrm{K}^{+}$ ATPase, i.e., the $\mathrm{Na}^{+}$and $\mathrm{K}^{+}$pump on the basolateral membranes. Low blood pressure, loss of blood, sodium depletion, or salt wasting activate intratubular RAS expression 
and generation of Ang II that, in turn, activates $\mathrm{AT}_{1}\left(\mathrm{AT}_{1 \mathrm{a}}\right)$ receptors to stimulate NHE3 expression and increase $\mathrm{Na}^{+}$reabsorption in the proximal tubules. These responses, along with other central neural, cardiovascular, and humoral factors help restore body salt and fluid balance and blood pressure homeostasis. By contrast, acute and chronic increases in blood pressure induces NHE3 endocytosis or redistribution from apical membranes, which augments the pressure-natriuresis response and induces diuresis and natriuresis that helps restore blood pressure to control [13-15].

NHE3 in the proximal tubules is the major downstream target of intratubular Ang II via $\mathrm{AT}_{1}\left(\mathrm{AT}_{1 \mathrm{a}}\right)$ receptors in the proximal tubules $[15,69]$. Physiologically, Ang II binds and activates $\mathrm{AT}_{1}\left(\mathrm{AT}_{1 \mathrm{a}}\right)$ and $\mathrm{AT}_{2}$ receptors in the proximal tubules, with $\mathrm{AT}_{1}\left(\mathrm{AT}_{1 \mathrm{a}}\right)$ receptors playing a dominant role $[13,15]$ and $\mathrm{AT}_{2}$ receptors playing a smaller counterregulatory role $[30,70]$. Previous studies have shown that activation of $\mathrm{AT}_{1}\left(\mathrm{AT}_{1 \mathrm{a}}\right)$ receptors by $\mathrm{Ang}$ II mediates $\mathrm{G}$ protein-coupled, $\mathrm{PKC} \alpha, \mathrm{IP}_{3}$, and $\mathrm{Ca}^{2+} /$ calmodulin-dependent protein kinase II signaling to induce NHE3 expression and activity in cultured proximal tubule cells [55,71,72]. Other anti-natriuretic factors, such as glucocorticoids [73,74], glucagon, and insulin $[75,76]$, also stimulate proximal tubule $\mathrm{Na}^{+}$reabsorption, in part, by upregulating NHE3 expression in the kidney. Conversely, Ang II and its major metabolite Ang III reportedly activate $\mathrm{AT}_{2}$ receptor-mediated NO/cGMP signaling to induce NHE3 endocytosis and increased urinary $\mathrm{Na}^{+}$excretion [30,70]. The natriuretic peptide dopamine has also been shown to inhibit proximal tubule $\mathrm{Na}^{+}$reabsorption and induces natriuresis by inhibiting NHE3 expression in the kidney [67,77-80]. Nevertheless, marked upregulation of intratubular Ang II/ $\mathrm{AT}_{1}\left(\mathrm{AT}_{1 \mathrm{a}}\right)$ receptors/NHE3 signaling in the proximal tubules plays a more dominant role in the development of Ang II-induced hypertension.

\section{4. $\mathrm{AT}_{1}\left(\mathrm{AT}_{1 \mathrm{a}}\right)$ Receptors in the Proximal Tubules of the Kidney Are Required for Maintaining Basal Blood Pressure Homeostasis}

It has long been recognized that the proximal tubules play a key role in overall blood pressure regulation and the development of hypertension. This recognition is based on the fact that approximately $65-70 \%$ of $\mathrm{Na}^{+}$and fluid is reabsorbed by the proximal tubules alone; thus, increases or decreases in proximal tubule reabsorption will exert a significant impact on blood pressure homeostasis [20]. Several previous studies have suggested that distal tubular segments may also play important roles in blood pressure regulation and the development of hypertension due to the fact of their ability to fully compensate for any increases or decreases in $\mathrm{Na}^{+}$delivery from the proximal tubules [81-83]. However, recent studies from our and other labs suggest otherwise, because distal nephron segments fail to compensate for the loss of $\mathrm{AT}_{1}\left(\mathrm{AT}_{1 \mathrm{a}}\right)$ receptors or its major downstream target $\mathrm{Na}^{+}$ transporter NHE3 in the proximal tubules, leading to inhibition of proximal tubule $\mathrm{Na}^{+}$ reabsorption, natriuretic response, and lower basal blood pressure [13,15,27].

As mentioned previously, all major components of the RAS, including angiotensinogen, renin, $\mathrm{ACE}$, and $\mathrm{AT}_{1}$ and $\mathrm{AT}_{2}$ receptors, have all been localized in the proximal tubules of the kidney [17-20]. Ang II concentrations in the proximal tubules are much higher than in the circulation under both the physiological and hypertensive states [84-87]. This may be due to several factors, including, but not limited to, (a) the expression of the substrate angiotensinogen and key enzymes renin and ACE for the generation of Ang II onsite; (b) the capacity of $\mathrm{AT}_{1}\left(\mathrm{AT}_{1 \mathrm{a}}\right)$ receptor- and the endocytic receptor megalin-mediated accumulation of circulating and tissue paracrine Ang II by the proximal tubules [88-90]; and (c) the feedforward regulatory mechanisms of intratubular RAS in the proximal tubules during the development of Ang II-induced hypertension [87,91]. Thus, it is expected that Ang II in the proximal tubules not only acts physiologically to stimulate proximal tubule reabsorption of sodium and fluid, maintain body sodium and fluid balance and basal blood pressure homeostasis, but also promotes sodium retention in hypertension via the actions of $\mathrm{AT}_{1}\left(\mathrm{AT}_{1 \mathrm{a}}\right)$ receptors $[56,92,93]$.

Although previous studies have shown that Ang II has biphasic effects to regulate proximal tubule sodium transport based on in vivo micropuncture experiments [93,94] or 
in vitro proximal tubule perfusion studies [78,95], whether these local effects alter systemic blood pressure has not been studied by these approaches. Whole body loss of function (deletion) or gain of function (overexpression) of the RAS may also be unable to determine the roles of intratubular Ang II and $\mathrm{AT}_{1}\left(\mathrm{AT}_{1 \mathrm{a}}\right)$ receptors in the proximal tubules of the kidney on basal blood pressure level and the development of Ang II-induced hypertension. At the whole kidney level, Crowley et al. were instrumental in demonstrating a key role of the kidney RAS in blood pressure control and in Ang II-induced hypertension using the cross-kidney transplantation approach between wild-type and whole-body Agtr1amice [10,96]. Their study elegantly showed that transplantation of $A g t r 1 a^{-/-}$mouse kidneys into wild-type mice lowered basal blood pressure and attenuated Ang II-induced hypertension, whereas transplantation of wild-type mouse kidneys into Agtr $1 a^{-/}$mice elevated blood pressure $[10,96]$. These studies directly support a key role for kidney $\mathrm{AT}_{1}$ $\left(\mathrm{AT}_{1 \mathrm{a}}\right)$ receptors in blood pressure control and Ang II-induced hypertension, but the role of intratubular $\mathrm{AT}_{1}\left(\mathrm{AT}_{1 \mathrm{a}}\right)$ receptors in the proximal tubules was not determined in these studies.

Two other instrumental studies have determined the role of $\mathrm{AT}_{1}\left(\mathrm{AT}_{1 \mathrm{a}}\right)$ receptors in the proximal tubules of the kidney using the Cre/LoxP approach with two different "proximal tubule-specific" promoters [27,97]. Gurley et al. used the PEPCK-Cre/Agtr1a flox [27], whereas Li et al. used the KAP2-iCre/Agtr1a flox approach to generate proximal tubule-specific $\mathrm{AT}_{1 \mathrm{a}}$-knockout mutant mice [97]. Both studies showed that intratubular $\mathrm{AT}_{1 \mathrm{a}}$ receptors regulate blood pressure with or without compensatory expression of NHE3, sodium and phosphate cotransporter $2\left(\mathrm{NaPi}_{2}\right), \mathrm{Na}^{+} / \mathrm{K}^{+}$-ATPase, sodium chloride cotransporter (NCC), $\mathrm{Na}^{+}: \mathrm{K}^{+}: \mathrm{Cl}^{2-}$ cotransporter 2 (NKCC2), and epithelial sodium channel (ENaC) in proximal or distal nephron segments $[27,97]$. However, PEPCK has been known to express, to some extent, in tissues beyond the proximal tubules, including other segments of the nephron and epithelial cells in many other extra-renal tissues such as the liver, white and brown fat, jejunum, ileum, and sublingual gland [98,99]. Likewise, the expression of renal androgen-regulated protein, KAP2, is not only confined to the proximal tubules, but also expressed in the outer medulla of the kidney and other tissues that physiologically respond to androgen $[100,101]$. While these studies suggest an important role of $\mathrm{AT}_{1}\left(\mathrm{AT}_{1 \mathrm{a}}\right)$ receptors in the proximal tubules, the specificity of the PEPCK or KAP2 promoters to the proximal tubules remain to be further determined.

Against this background, our lab has recently taken a different approach to generate a new mutant mouse model (PT-Agtr $1 a^{-/}$) with proximal tubule-specific deletion of $\mathrm{AT}_{1}$ receptors $\left(\mathrm{AT}_{1 \mathrm{a}}\right)$ in the kidney using the iL1-SGLT2-Cre/Agtr1a flox approach [16,28]. The scientific premise for using the iL1-SGLT2-Cre/Agtr1a flox approach was based on the findings that SGLT2, the sodium and glucose cotransporter 2, is more specific to the proximal tubules with its expression primarily, if not exclusively, in the S1 and S2 segments of the proximal tubules $[13,14,97,102]$. No SGLT2 is expressed in distal nephron segments beyond the end of the proximal tubules or in other tissues such as brain, blood vessels, heart, or liver $[102,103]$. With this new approach, our studies consistently showed that selective deletion of Agtr1a in the proximal tubules led to an appropriate $15 \pm 3 \mathrm{mmHg}$ decrease in basal systolic, diastolic, and mean arterial blood pressure in both male and female PTAgtr1 $1 a^{-/-}$mice when compared to wild-type mice (Figure 2) [16,28]. By contrast, deletion of $\mathrm{AT}_{1 \mathrm{a}}$ receptors in all tissues of the body led to an approximately $30 \pm 5 \mathrm{mmHg}$ lower systolic, diastolic, and mean arterial blood pressure in global Agtr1 $a^{-/-}$mice $[11,16,28,55]$. No significant sex differences in this basal blood pressure phenotype were observed in either global Agtr1a $a^{-/}$or proximal tubule-specific PT-Agtr1 $a^{-/-}$mice $[12,28]$. The blood pressure-lowering effect in PT-Agtr $1 a^{-/-}$mice was associated with significant diuretic and natriuretic responses and increases in the basal glomerular filtration rate as well as the pressure-natriuresis response due to the inhibition of $\mathrm{Na}^{+}$and fluid reabsorption in the proximal tubules (Figure 2) $[28,104,105]$. Our data strongly support the hypothesis that intratubular Ang II via actions on $\mathrm{AT}_{1 \mathrm{a}}$ receptors in the proximal tubules, indeed, play a key 
role in maintaining basal blood pressure homeostasis, and loss of $\mathrm{AT}_{1 \mathrm{a}}$ receptor function in the proximal tubules would lower basal blood pressure.

A.

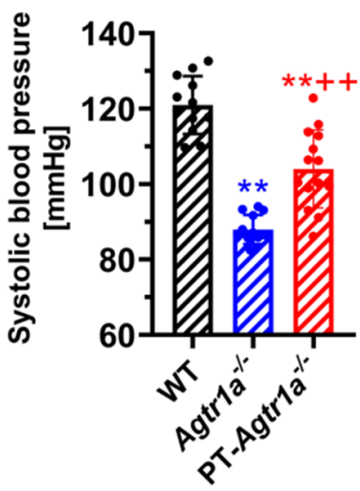

D.

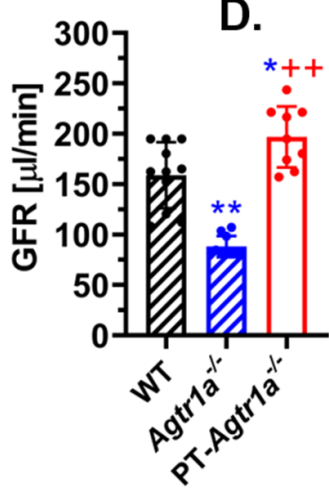

B.
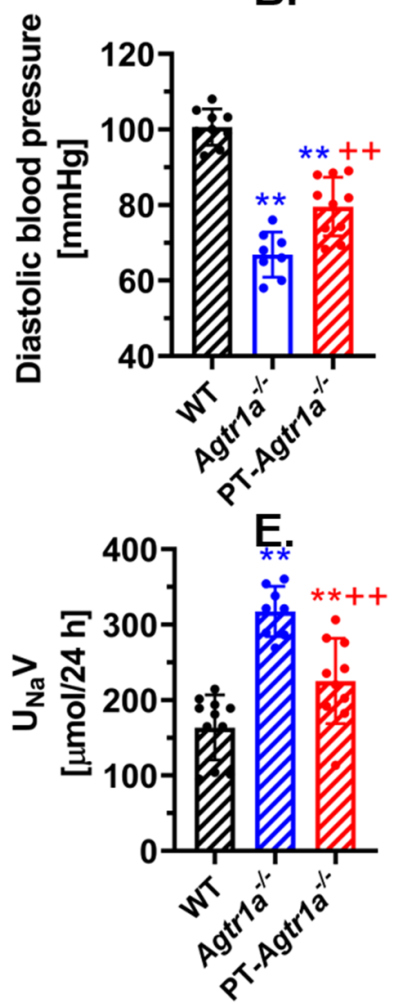

C.

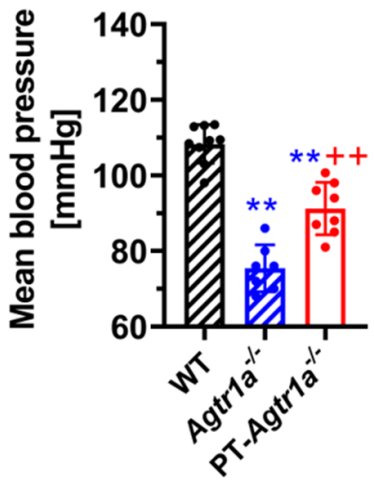

F.

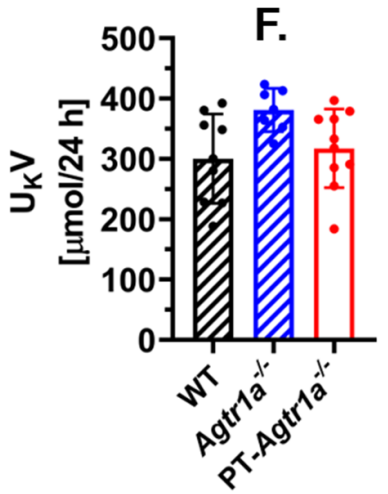

Figure 2. Effects of global or proximal tubule-selective deletion of $\mathrm{AT}_{1 \mathrm{a}}$ receptors on basal systolic, diastolic, and mean arterial blood pressure (A-C), glomerular filtration rate (D), and natriuretic response (E) in whole-body Agtr1a ${ }^{-/}$or proximal tubule-specific PT-Agtr1a ${ }^{-/}$mice compared with wild-type mice. Note that Agtr1 $a^{-/-}$mice showed that basal blood pressure was $\sim 30 \mathrm{mmHg}$ lower than wild-type mice, whereas PT-Agtr1 $a^{-/}$mice had basal blood pressure $15 \mathrm{mmHg}$ lower than wild-type mice, respectively. (F) shows no changes in $24 \mathrm{~h}$ urinary potassium excretion. ${ }^{*} p<0.05$ or ${ }^{* *} p<0.01$ vs. WT mice; ${ }^{++} p<0.01$ vs. global Agtr1a ${ }^{-/-}$mice. Reproduced from Reference [28] with permission.

\section{5. $\mathrm{AT}_{1}\left(\mathrm{AT}_{1 \mathrm{a}}\right)$ Receptors in the Proximal Tubules of the Kidney Are Required for the Development of Ang II-Induced Hypertension}

The development of Ang II-induced hypertension has been extensively studied in different animal models with $\mathrm{AT}_{1}\left(\mathrm{AT}_{1 \mathrm{a}}\right)$ receptors playing the fundamental role $[12,27,71,97,104]$. $\mathrm{AT}_{1}\left(\mathrm{AT}_{1 \mathrm{a}}\right)$ receptors are expressed widely, although to different levels, in the brain, adrenal glands, and cardiovascular and kidney tissues; thus, the mechanisms underlying Ang II-induced hypertension are expected to involve different tissues or pathways $[16,39]$. We and others have recently determined the direct contributions of intratubular Ang II via $\mathrm{AT}_{1}\left(\mathrm{AT}_{1 \mathrm{a}}\right)$ receptors in the proximal tubules in the development of Ang IIinduced hypertension by comparing global, kidney-, and proximal tubule-specific Agtr1 $a^{-/-}$ mice $[10-12,16,27,28,97,104]$. As discussed previously in the cross-kidney transplantation study, Crowley et al. reported that kidney $\mathrm{AT}_{1}\left(\mathrm{AT}_{1 \mathrm{a}}\right)$ receptors played virtually equivalent roles in $\mathrm{AT}_{1}$ receptor actions in the kidney and in extrarenal tissues to determining the level of blood pressure and the development of Ang II-infused hypertension [10,96]. Gurley et al. showed that deletion of $\mathrm{AT}_{1 \mathrm{a}}$ receptors in mice significantly attenuated Ang II-induced hypertension in their mouse model generated using the PEPCK-Cre/Agtr1a flox approach [27]. By contrast, $\mathrm{Li} \mathrm{H}$. et al. demonstrated that Ang II action via the proximal tubule $\mathrm{AT}_{1 \mathrm{a}}$ receptors was not a significant component of the acute pressor action of increased circulating Ang II, i.e., in Ang II-induced hypertensive response and in their mouse model generated using 
the KAP2-iCre/Agtr1a flox approach [97]. We recently studied the roles and mechanisms responsible for the development of Ang II-induced hypertension using global and proximal tubule-specific $A g t r 1 a^{-/-}$mice $[12,16,28]$. We induced Ang II-induced hypertension in male and female wild-type, global Agtr1a-- and proximal tubule-specific Agtr1 $a^{-/-}$mice by infusing exogenous Ang II (0.5-1.5 mg/ $\mathrm{kg} /$ day, i.p.) or by adenovirus-mediated overexpressing an intracellular cyan fluorescent protein tagged Ang II fusion protein, Ad-sglt2-ECFP/Ang II, selectively in the proximal tubules using the SGLT2 promoter [16,28]. In both scenarios, systemic Ang II infusion or proximal tubule-specific expressed Ang II fusion proteins significantly increased systolic, diastolic, and mean arterial blood pressure in wild-type mice, as expected. Global deletion of $\mathrm{AT}_{1}\left(\mathrm{AT}_{1 \mathrm{a}}\right)$ receptors completely prevented the development of hypertension by systemic or intratubular/intracellular Ang II, also as expected, because $\mathrm{AT}_{1}\left(\mathrm{AT}_{1 \mathrm{a}}\right)$ receptors mediated most if not all well-recognized hypertensive responses. By contrast, Ang II-induced hypertension by systemic Ang II infusion was markedly attenuated by $\sim 50 \%$ but not completely blocked in proximal tubule-specific PT-Agtr $1 a^{-/-}$mice (Figure 3) [12,28]. Interestingly, increases in blood pressure induced by proximal tubulespecific expression of Ang II fusion proteins in wild-type mice were completed blocked in proximal tubule-specific PT-Agtr1 $a^{-/-}$mice $[16,28]$.

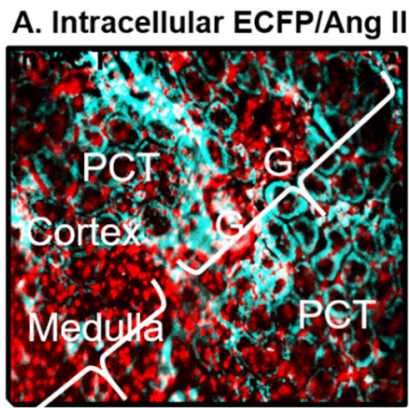

D. Extracellular Ang II

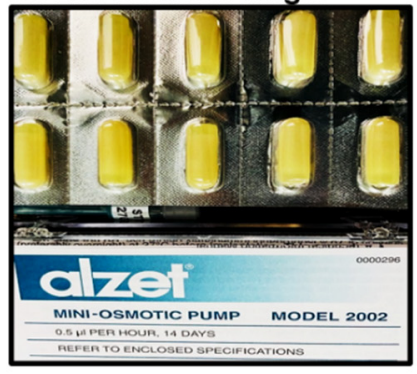

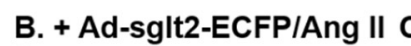

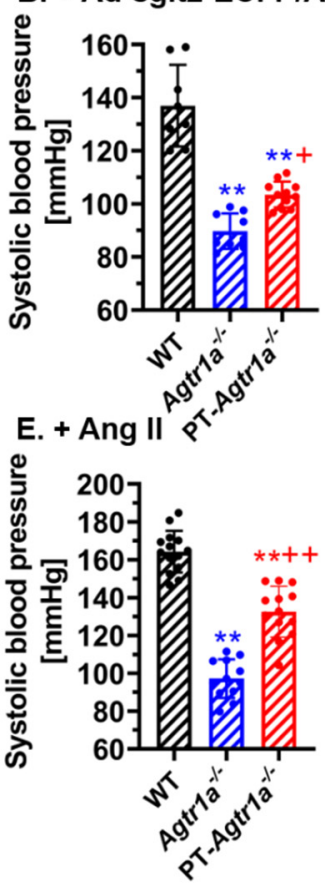

C. + Ad-sglt2-ECFPIAng II + Los

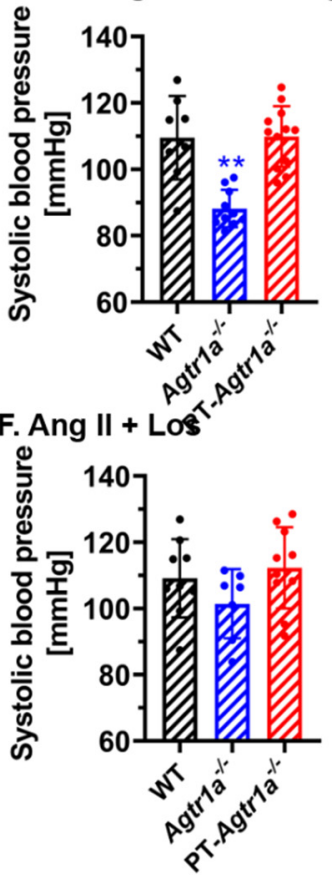

Figure 3. Angiotensin II-induced hypertension by adenovirus-mediated, sglt2 promoter-driven proximal tubule-specific overexpression of an intracellular Ang II fusion protein Ad-sglt2-ECFP/Ang II in the kidney (A-C), or osmotic minipump infusion of a pressor dose of Ang II (D-F) in wildtype mice was significantly attenuated in proximal tubule-specific PT-Agtr1 $a^{-/-}$mice. In response to proximal tubule-specific overexpression of Ad-sglt2-ECFP/Ang II, blood pressure was elevated by $17 \pm 3 \mathrm{mmHg}$ in wild-type mice, and the increase was totally blocked in PT-Agtr1 $a^{-/-}$mice (B). Infusion of a high pressor dose of Ang II for 2 weeks $(1.5 \mathrm{mg} / \mathrm{kg} /$ day, i.p.) markedly increased blood pressure by $>45 \mathrm{mmHg}$ in wild-type mice, and this increase was attenuated by half in PTAgtr1a ${ }^{-/}$mice (E). Concurrent treatment with the $\mathrm{AT}_{1}$ receptor blocker losartan $(20 \mathrm{mg} / \mathrm{kg} /$ day, p.o. $)$ normalized blood pressure to the wild-type control levels. ${ }^{* *} p<0.01$ vs. wild type; ${ }^{+} p<0.05$ or ${ }^{++} p<0.01$ vs. Agtr1 $a^{-/-}$mice. Reproduced from Reference [28] with permission.

How increases in blood pressure by proximal tubule-specific overexpression of intracellular Ang II fusion protein were completely blocked, whereas Ang II-induced hypertension by systemic Ang II infusion was attenuated by only $~ 50 \%$ in PT-Agtr $1 a^{-/-}$mice, remains 
incompletely understood. However, both systemic and proximal tubule-specific $\mathrm{AT}_{1}$ $\left(\mathrm{AT}_{1 \mathrm{a}}\right)$ receptor-dependent mechanisms are expected to mediate the development of Ang II-induced hypertension $[10,13,26,27,29]$. Deletion of $\mathrm{AT}_{1}\left(\mathrm{AT}_{1 \mathrm{a}}\right)$ receptors selectively in the proximal tubules of PT-Agtr1 $1 a^{-/}$mice only blocks $\mathrm{AT}_{1}\left(\mathrm{AT}_{1 \mathrm{a}}\right)$ receptor- and NHE3-mediated stimulation of proximal tubule $\mathrm{Na}^{+}$reabsorption, but has no effects beyond the proximal tubules in the kidney and other extrarenal tissues $[14,15,27,29,71]$. Conversely, in the studies with proximal tubule-specific overexpression of intracellular Ang II fusion protein, intracellular Ang II does not induce systemic effects. This is because intracellular Ang II fusion protein only activates intracellular $\mathrm{AT}_{1}\left(\mathrm{AT}_{1 \mathrm{a}}\right)$ receptors confined to the proximal tubules to stimulate proximal tubule $\mathrm{Na}^{+}$reabsorption, which elevates blood pressure $[71,106,107]$. Thus, deletion of $\mathrm{AT}_{1}\left(\mathrm{AT}_{1 \mathrm{a}}\right)$ receptors selectively in the proximal tubules of PT-Agtr1amice is expected completely to block intracellular Ang II-induced blood pressure increases by blocking intracellular Ang II-stimulated proximal tubule $\mathrm{Na}^{+}$reabsorption.

\section{Sex Differences in Ang II-Induced Hypertension}

Recently, sex differences in genetics, biology, physiology, and cardiovascular, kidney, and hypertensive diseases have attracted widespread attention and extensive research focus [108-113]. This is largely due to the recent mandates in the NIH Policies for Biomedical Research to consider and include gender- and/or sex-related factors as biological variables in all experimental designs [114-117]. Although great progress has been made in sex differences in many other research fields, sex differences in basal blood pressure control or in Ang II-induced hypertension have been inconsistent between different studies or animal models. Specifically, some sex differences have been found in the blood pressure or tubuloglomerular feedback (TGF) responses to Ang II [108-111], increases in $\mathrm{NaCl}$ cotransporter or ENaC expression in response to Ang II [118,119], the development of Ang II-induced hypertension [113], diabetic nephropathy [120], or abdominal aortic aneurysms [121]. However, whether sex differences are involved in intratubular Ang II and its $\mathrm{AT}_{1 \mathrm{a}}$ receptors in the proximal tubules in the development of Ang II-induced hypertension has not been studied previously.

Against this background, we have recently tested the hypothesis that there are significant sex differences in the roles of intratubular Ang II via $\mathrm{AT}_{1 \mathrm{a}}$ receptors in the proximal tubules during the development of Ang II-induced hypertension [12]. Specifically, we hypothesized that $\mathrm{AT}_{1 \mathrm{a}}$ receptors in the proximal tubules of female mice contribute less to Ang II-induced hypertension than those in male mice. To test this hypothesis, we directly compared the blood pressure, glomerular, and tubular responses to Ang II-induced hypertension in adult male and female wild-type and mutant mice with proximal tubule-specific knockout of $\mathrm{AT}_{1 \mathrm{a}}$ receptors (PT-Agtr1a $a^{--}$) [12]. When adult male and female wild-type and PT-Agtr1a ${ }^{-/}$mice were infused with or without an identical pressor dose of Ang II via osmotic pump for 2 weeks ( $1.5 \mathrm{mg} / \mathrm{kg} /$ day, i.p.), we found that basal systolic, diastolic, and mean arterial pressure were approximately $13 \pm 3 \mathrm{mmHg}$ lower, while basal $24 \mathrm{~h}$ urinary $\mathrm{Na}^{+}$excretion was significantly higher in both male and female PT-Agtr1a $a^{-/}$mice than wild-type controls without significant sex differences in the same strain (Figure 4). Both male and female wild-type mice developed marked hypertension with similar magnitudes of the pressor responses to Ang II, also without significant sex differences. Furthermore, Ang II-induced hypertension was equally attenuated in male and female PT-Agtr $1 a^{-/-}$mice with or without concurrent blockade of $\mathrm{AT}_{1}$ receptors with losartan [28]. Finally, Ang II-induced glomerular and tubulointerstitial injury was attenuated in both male and female PT-Agtr1a ${ }^{-/}$mice. Taken together, our study shows that deletion of $\mathrm{AT}_{1 \mathrm{a}}$ receptors in the proximal tubules of the kidney attenuated Ang II-induced hypertension and kidney injury without revealing significant sex differences. 


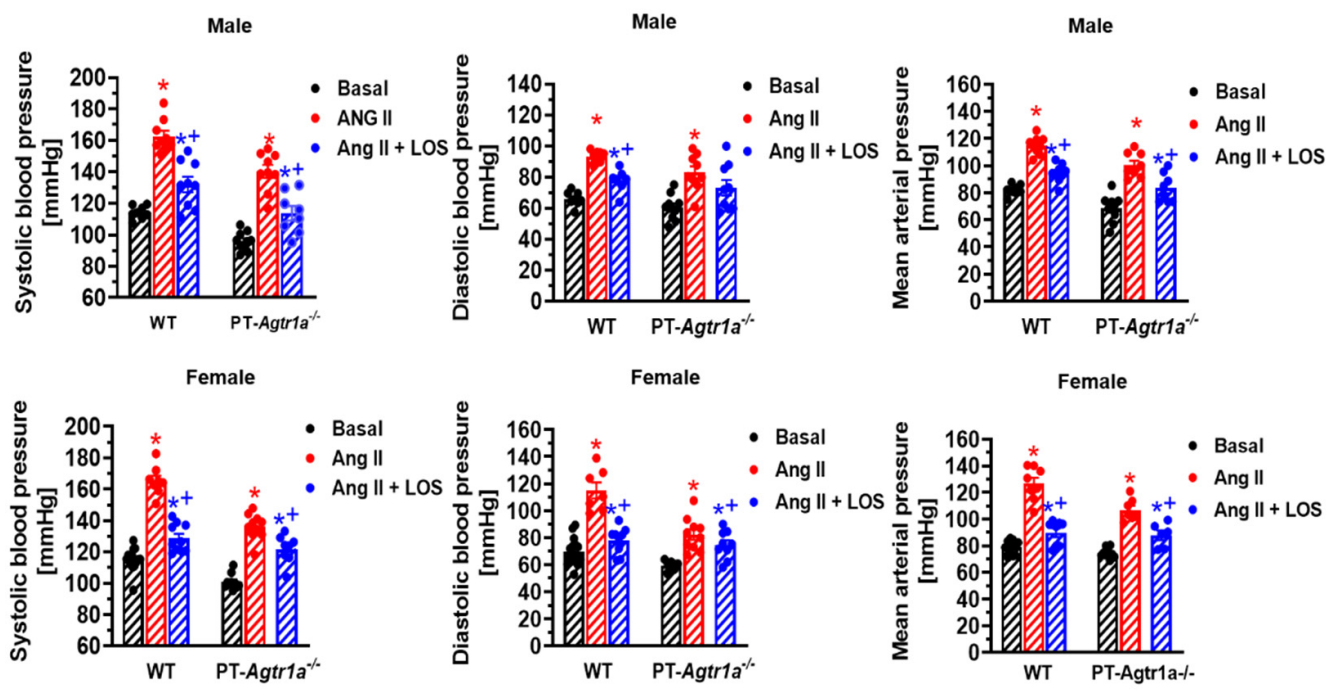

Figure 4. Basal systolic, diastolic, and mean arterial blood pressure and in response to osmotic minipump infusion of a high pressor dose of Ang II with or without $\mathrm{AT}_{1}\left(\mathrm{AT}_{1 \mathrm{a}}\right)$ receptor blocker losartan for two weeks in adult male and female wild-type and PT-Agtr1a ${ }^{-/}$mice. Note that deletion of $\mathrm{AT}_{1 \mathrm{a}}$ receptors selectively in the proximal tubules significantly decreased basal blood pressure by $\sim 13-15 \pm 3 \mathrm{mmHg}$ similarly in male and female PT-Agtr1a ${ }^{--}$mice under basal conditions. In addition, Ang II-induced hypertension was significantly attenuated in both male and female PT-Agtr1a ${ }^{-/-}$mice. ${ }^{*} p<0.05$ vs. control WT or PT-Agtr $1 a^{-/-}$mice; ${ }^{+} p<0.05$ vs. Ang II-infused male or female wild-type or PT-Agtr1a ${ }^{-/-}$mice. Reproduced from Reference [12] with permission.

\section{Roles of Proximal Tubule Atrial Natriuretic Peptide, Dopamine, or Prorenin Receptors in Ang II-Induced Hypertension}

Although the basal blood pressure phenotypes and their responses to Ang II-induced hypertension in proximal tubule-specific PT-Agtr1 $a^{-/-}$mice are primarily due to the loss of $\mathrm{AT}_{1 \mathrm{a}}$ receptors in the proximal tubules, the roles or involvement of other intratubular vasoactive factors may also be considered. One of these factors is $G$ protein-coupled receptors for atrial natriuretic factor or peptide (ANP), especially NPR $\mathrm{A}_{\mathrm{A}}$. ANP receptors $\left(\mathrm{NPR}_{\mathrm{A}}\right)$ are expressed strongly in the proximal tubules in addition to the glomerulus, distal tubules, and collecting ducts [122-124], and ANP acts on $\mathrm{NPR}_{\mathrm{A}}$ in the proximal tubules of the kidney to counteract the effects of Ang II by inhibiting proximal tubule $\mathrm{Na}^{+}$ reabsorption [125-127]. Thus, it is expected that deletion of $\mathrm{AT}_{1 \mathrm{a}}$ receptors in the proximal tubules may augment the natriuretic response to $\mathrm{NPR}_{\mathrm{A}}$-mediated effects in the proximal tubules. However, no such study has been reported to determine whether ANP-induced natriuretic response is potentiated in PT-Agtr1a $a^{--}$mice. The other factor is dopamine receptors in the proximal tubules. Dopamine receptors are also expressed in the proximal tubules of the kidney, which mediate the natriuretic responses to dopamine administration and counteract the anti-natriuretic effects of $\mathrm{AT}_{1}\left(\mathrm{AT}_{1 \mathrm{a}}\right)$ receptors [128-130]. Prorenin receptors (PRR) are also expressed in the proximal tubules of the kidney in addition to the glomerulus, distal tubules, and collecting ducts [131,132]. The roles of PRR in the proximal tubules remain unknown. Soluble PRR reportedly promotes the fibrotic response in renal proximal tubule epithelial cells in vitro via the Akt/ $\beta$-catenin/Snail signaling pathway [131], whereas deletion of nephron PRR (ATP6AP2) has been shown to impair proximal tubule function in mice [132]. However, reviewing and discussing the roles of $\mathrm{NPR}_{\mathrm{A}}$, dopamine receptors, or PRR in the proximal tubules of the kidney in details are beyond the scope of this article. Future studies are necessary to confirm whether $\mathrm{NPR}_{\mathrm{A}}$, PRR, or dopamine receptors are involved in mediating basal blood pressure and natriuretic phenotypes and in the development of Ang II-induced hypertension. 


\section{Conclusions and Perspectives}

In summary, we have gained new insights into the important roles of intratubular Ang II and $\mathrm{AT}_{1}\left(\mathrm{AT}_{1 \mathrm{a}}\right)$ receptors in the proximal tubules of the kidney in maintaining basal blood pressure homeostasis and the development of Ang II-induced hypertension. Significant progress has been made directly in a few key areas over the last three decades, but other studies may also independently contribute to the progresses. Specifically, early in vivo proximal tubule micropuncture experiments in rats $[93,94]$ and in vitro isolated proximal tubule perfusion studies in rabbits or rats $[78,95]$ established important milestones by demonstrating direct biphasic effects of Ang II on proximal tubule $\mathrm{Na}^{+}$transport function. This was followed by subsequent loss or gain of $\mathrm{AT}_{1}\left(\mathrm{AT}_{1 \mathrm{a}}\right)$ receptor function studies in mice using the kidney-cross transplantation between wild-type and $A g t r 1 a^{-/-}$mice, firmly confirming the critical role of kidney $\mathrm{AT}_{1}\left(\mathrm{AT}_{1 \mathrm{a}}\right)$ receptors in blood pressure control and hypertension [10,96]. However, these studies have not be able to determine the direct role of intratubular Ang II and $\mathrm{AT}_{1}\left(\mathrm{AT}_{1 \mathrm{a}}\right)$ receptors in the proximal tubules in blood pressure control and Ang II-induced hypertension. Recent development in the Cre/LoxP approach has significantly helped advance new insights into the role of proximal tubule Ang II and $\mathrm{AT}_{1}\left(\mathrm{AT}_{1 \mathrm{a}}\right)$ receptors. This novel approach has provided us and others with an important tool to generate novel mouse models with proximal tubule-specific loss (deletion) or gain of the function (overexpression) $[12-14,16,27,28,97]$. These new studies have consistently demonstrated that deletion of $\mathrm{AT}_{1}\left(\mathrm{AT}_{1 \mathrm{a}}\right)$ receptors $[12,15,16]$ or its direct downstream target, NHE3, selectively in the proximal tubules of the kidney $[13,14]$ lowers basal blood pressure, increases the pressure-natriuresis response, and induces natriuretic responses, whereas overexpression of an intracellular Ang II fusion protein or $\mathrm{AT}_{1}\left(\mathrm{AT}_{1 \mathrm{a}}\right)$ receptors selectively in the proximal tubules increases proximal tubule $\mathrm{Na}^{+}$reabsorption, impairs the pressure-natriuresis response, and elevates blood pressure [71,106,107]. Furthermore, since the development of Ang II-induced hypertension by systemic Ang II infusion or by proximal tubule-specific overexpression of an intracellular Ang II fusion protein was attenuated in mutant mice with proximal tubule-specific deletion of $\mathrm{AT}_{1 \mathrm{a}}[12,16,28]$ or NHE3 [13,69], we may conclude that intratubular Ang II via $\mathrm{AT}_{1 \mathrm{a}}$ and NHE3 in the proximal tubules play a key role in maintaining basal blood pressure and the development of Ang II-induced hypertension.

Author Contributions: Conceptualization: J.L.Z. and X.C.L.; Writing—draft preparations: A.P.d.O.L., S.M.N., X.C.L. and J.L.Z.; Participants in experiments: A.P.d.O.L., X.C.L., R.H. and S.M.N.; Review and editing: J.L.Z. and X.C.L.; Finalization: A.P.d.O.L., S.M.N., J.L.Z. and X.C.L. All authors have read and agreed to the published version of the manuscript.

Funding: This work was supported in part by grants from the National Institute of Diabetes and Digestive and Kidney Diseases (2R01DK102429-03A1, 2R01DK067299-10A1, and 1R01DK102429-01) and the National Heart, Lung, and Blood Institute (1R56HL130988-01) to J.L.Z.

Institutional Review Board Statement: Not applicable.

Informed Consent Statement: All animal studies from the authors and cited in this article were approved by the IACUC of the University of Mississippi Medical Center and Tulane University School of Medicine.

Data Availability Statement: Not applicable.

Acknowledgments: All animal studies were performed with data collected in the laboratory of Jia Zhuo at the University of Mississippi Medical Center in Jackson, Mississippi, and Tulane University School of Medicine, New Orleans, Louisiana. We thank Isabelle Rubera and Michell Tauc from the Laboratoire de Physiomédecine Moléculaire, LP2M, UMR-CNRS 7370, Université Côte d'Azur, Nice CEDEX 2, France (I.R., M.T.) for providing breeding pairs of iL1-sglt2-Cre mouse strain for us to generate proximal tubule-specific PT-Agtr1a $a^{-/-}$mice in our studies. The contributions of our past and current technicians and postdoctoral fellows from their excellent technical assistance are greatly appreciated.

Conflicts of Interest: The authors declare no conflict of interest. 


\section{References}

1. Ostchega, Y.; Fryar, C.D.; Nwankwo, T.; Nguyen, D.T. Hypertension Prevalence Among Adults Aged 18 and Over: United States, 2017-2018. NCHS Data Brief 2020, 1-8. Available online: https://stacks.cdc.gov/view/cdc/87559 (accessed on 18 January 2022).

2. Whelton, P.K. The Elusiveness of Population-Wide High Blood Pressure Control. Annu. Rev. Public Health 2015, 36, 109-130. [CrossRef] [PubMed]

3. Whelton, P.K.; Carey, R.M.; Aronow, W.S.; Casey, D.E.; Collins, K.J.; Dennison Himmelfarb, C.; DePalma, S.M.; Gidding, S.; Jamerson, K.A.; Jones, D.W.; et al. 2017 ACC/AHA/AAPA/ABC/ACPM/AGS/APhA/ASH/ASPC/NMA/PCNA Guideline for the Prevention, Detection, Evaluation, and Management of High Blood Pressure in Adults: Executive Summary: A Report of the American College of Cardiology/American Heart Association Task Force on Clinical Practice Guidelines. Hypertension 2018, 71, 1269-1324. [CrossRef] [PubMed]

4. Carey, R.M.; Sakhuja, S.; Calhoun, D.A.; Whelton, P.K.; Muntner, P. Prevalence of Apparent Treatment-Resistant Hypertension in the United States. Hypertension 2019, 73, 424-431. [CrossRef]

5. Wright, J.M.; Musini, V.M.; Gill, R. First-line Drugs for Hypertension. Cochrane Database Syst. Rev. 2018, 2018, CD001841. [CrossRef]

6. Shrout, T.; Rudy, D.W.; Piascik, M.T. Hypertension Update, JNC8 and Beyond. Curr. Opin. Pharmacol. 2017, 33, 41-46. [CrossRef]

7. Aronow, W.S. Association of Obesity with Hypertension. Ann. Transl. Med. 2017, 5, 350. [CrossRef]

8. Ivy, J.R.; Bailey, M.A. Pressure Natriuresis and the Renal Control of Arterial Blood Pressure. J. Physiol. 2014, 592, 3955-3967. [CrossRef]

9. Chappell, M.C. Nonclassical Renin-Angiotensin System and Renal Function. Compr. Physiol. 2012, 2, 2733-2752. [CrossRef]

10. Crowley, S.D.; Gurley, S.B.; Oliverio, M.I.; Pazmino, A.K.; Griffiths, R.; Flannery, P.J.; Spurney, R.F.; Kim, H.-S.; Smithies, O.; Le, T.H.; et al. Distinct Roles for the Kidney and Systemic Tissues in Blood Pressure Regulation by the Renin-Angiotensin System. J. Clin. Investig. 2005, 115, 1092-1099. [CrossRef]

11. Li, X.C.; Cook, J.L.; Rubera, I.; Tauc, M.; Zhang, F.; Zhuo, J.L. Intrarenal Transfer of an Intracellular Fluorescent Fusion of Angiotensin II Selectively in Proximal Tubules Increases Blood Pressure in Rats and Mice. Am. J. Physiol. Ren. Physiol. 2011, 300, F1076-F1088. [CrossRef] [PubMed]

12. Leite, A.P.O.; Li, X.C.; Hassan, R.; Zheng, X.; Alexander, B.T.; Casarini, D.E.; Zhuo, J.L. Sex Differences in Angiotensin II-Induced Hypertension and Kidney Injury: Role of $\mathrm{AT}_{1 \mathrm{a}}$ Receptors in The Proximal Tubule of The Kidney. Clin. Sci. 2021, 135, 1825-1843. [CrossRef] [PubMed]

13. Li, X.C.; Soleimani, M.; Zhu, D.; Rubera, I.; Tauc, M.; Zheng, X.; Zhang, J.; Chen, X.; Zhuo, J.L. Proximal Tubule-Specific Deletion of the NHE3 $(\mathrm{Na}+/ \mathrm{H}+$ Exchanger 3) Promotes the Pressure-Natriuresis Response and Lowers Blood Pressure in Mice. Hypertension 2018, 72, 1328-1336. [CrossRef] [PubMed]

14. Li, X.C.; Zhu, D.; Chen, X.; Zheng, X.; Zhao, C.; Zhang, J.; Soleimani, M.; Rubera, I.; Tauc, M.; Zhou, X.; et al. Proximal TubuleSpecific Deletion of the NHE3 (Na+/H+ Exchanger 3) in the Kidney Attenuates Ang II (Angiotensin II)-Induced Hypertension in Mice. Hypertension 2019, 74, 526-535. [CrossRef] [PubMed]

15. Li, X.C.; Wang, C.-H.; Leite, A.P.O.; Zhuo, J.L. Intratubular, Intracellular, and Mitochondrial Angiotensin II/AT1 (AT1a) Receptor/NHE3 Signaling Plays a Critical Role in Angiotensin II-Induced Hypertension and Kidney Injury. Front. Physiol. 2021, 12, 702797. [CrossRef] [PubMed]

16. Li, X.C.; Zhou, X.; Zhuo, J.L. Evidence for a Physiological Mitochondrial Angiotensin II System in the Kidney Proximal Tubules. Hypertension 2020, 76, 121-132. [CrossRef]

17. Kobori, H.; Nishiyama, A.; Harrison-Bernard, L.M.; Navar, L.G. Gabriel Urinary Angiotensinogen as an Indicator of Intrarenal Angiotensin Status in Hypertension. Hypertension 2003, 41, 42-49. [CrossRef]

18. Mendelsohn, F.A. Angiotensin II: Evidence for Its Role as an Intrarenal Hormone. Kidney Int. Suppl. 1982, 12, S78-S81.

19. Navar, L.G.; Kobori, H.; Prieto-Carrasquero, M. Intrarenal Angiotensin II and Hypertension. Curr. Hypertens. Rep. 2003, 5 , 135-143. [CrossRef]

20. Zhuo, J.L.; Li, X.C. Proximal Nephron. Compr. Physiol. 2013, 3, 1079-1123. [CrossRef]

21. Ardaillou, R. Active Fragments of Angiotensin II: Enzymatic Pathways of Synthesis and Biological Effects. Curr. Opin. Nephrol. Hypertens. 1997, 6, 28-34. [CrossRef] [PubMed]

22. Ardaillou, R.; Chansel, D. Synthesis and Effects of Active Fragments of Angiotensin II. Kidney Int. 1997, 52, 1458-1468. [CrossRef] [PubMed]

23. Pullman, T.N.; Oparil, S.; Carone, F.A. Fate of Labeled Angiotensin II Microinfused into Individual Nephrons in the Rat. Am. J. Physiol. 1975, 228, 747-751. [CrossRef] [PubMed]

24. Zhuo, J.L.; Li, X.C. New Insights and Perspectives on Intrarenal Renin-Angiotensin System: Focus on Intracrine/Intracellular Angiotensin II. Peptides 2011, 32, 1551-1565. [CrossRef]

25. Forrester, S.J.; Booz, G.W.; Sigmund, C.D.; Coffman, T.M.; Kawai, T.; Rizzo, V.; Scalia, R.; Eguchi, S. Angiotensin II Signal Transduction: An Update on Mechanisms of Physiology and Pathophysiology. Physiol. Rev. 2018, 98, 1627-1738. [CrossRef]

26. Kobori, H.; Nangaku, M.; Navar, L.; Nishiyama, A. The Intrarenal Renin-Angiotensin System: From Physiology to the Pathobiology of Hypertension and Kidney Disease. Pharmacol. Rev. 2007, 59, 251-287. [CrossRef] 
27. Gurley, S.B.; Riquier-Brison, A.D.M.; Schnermann, J.; Sparks, M.A.; Allen, A.M.; Haase, V.H.; Snouwaert, J.N.; Le, T.H.; McDonough, A.A.; Koller, B.H.; et al. AT1A Angiotensin Receptors in the Renal Proximal Tubule Regulate Blood Pressure. Cell Metab. 2011, 13, 469-475. [CrossRef]

28. Li, X.C.; Leite, A.P.O.; Zheng, X.; Zhao, C.; Chen, X.; Zhang, L.; Zhou, X.; Rubera, I.; Tauc, M.; Zhuo, J.L. Proximal Tubule-Specific Deletion of Angiotensin II Type 1a Receptors in the Kidney Attenuates Circulating and Intratubular Angiotensin II-Induced Hypertension in PT-Agtr1a ${ }^{-/-}$Mice. Hypertension 2021, 77, 1285-1298. [CrossRef]

29. Li, X.C.; Zhuo, J.L. Phosphoproteomic Analysis of AT1 Receptor-Mediated Signaling Responses in Proximal Tubules of Angiotensin II-Induced Hypertensive Rats. Kidney Int. 2011, 80, 620-632. [CrossRef]

30. Kemp, B.A.; Howell, N.L.; Gildea, J.J.; Keller, S.R.; Padia, S.H.; Carey, R.M. AT2 Receptor Activation Induces Natriuresis and Lowers Blood Pressure. Circ. Res. 2014, 115, 388-399. [CrossRef]

31. Kemp, B.A.; Howell, N.L.; Keller, S.R.; Gildea, J.J.; Padia, S.H.; Carey, R.M. AT2 Receptor Activation Prevents Sodium Retention and Reduces Blood Pressure in Angiotensin II-Dependent Hypertension. Circ. Res. 2016, 119, 532-543. [CrossRef] [PubMed]

32. Li, X.C.; Widdop, R.E. AT2 Receptor-Mediated Vasodilatation Is Unmasked by AT1 Receptor Blockade in Conscious SHR. Br. J. Pharmacol. 2004, 142, 821-830. [CrossRef] [PubMed]

33. Siragy, H.M.; Inagami, T.; Ichiki, T.; Carey, R.M. Sustained Hypersensitivity to Angiotensin II and Its Mechanism in Mice Lacking the Subtype-2 (AT2) Angiotensin Receptor. Proc. Natl. Acad. Sci. USA 1999, 96, 6506-6510. [CrossRef]

34. Elton, T.S.; Stephan, C.C.; Taylor, G.R.; Kimball, M.G.; Martin, M.M.; Durand, J.N.; Oparil, S. Isolation of Two Distinct Type I Angiotensin II Receptor Genes. Biochem. Biophys. Res. Commun. 1992, 184, 1067-1073. [CrossRef]

35. Iwai, N.; Inagami, T. Isolation of Preferentially Expressed Genes in the Kidneys of Hypertensive Rats. Hypertension 1991, 17, 161-169. [CrossRef] [PubMed]

36. Murphy, T.J.; Alexander, R.W.; Griendling, K.K.; Runge, M.S.; Bernstein, K.E. Isolation of a CDNA Encoding the Vascular Type-1 Angiotensin II Receptor. Nature 1991, 351, 233-236. [CrossRef]

37. Sasaki, T.; Ogihara-Umeda, I.; Kojima, S.; Nishigori, H. Sequential Enzymatic Synthesis and Biodistribution of Radiolabelled Inositol and Inositol Analogs. Int. J. Rad. Appl. Instrum. 1991, 42, 97-101. [CrossRef]

38. De Gasparo, M.; Catt, K.J.; Inagami, T.; Wright, J.W.; Unger, T. International Union of Pharmacology. XXIII. The Angiotensin II Receptors. Pharmacol. Rev. 2000, 52, 415-472.

39. Li, X.C.; Zhu, D.; Zheng, X.; Zhang, J.; Zhuo, J.L. Intratubular and Intracellular Renin-Angiotensin System in the Kidney: A Unifying Perspective in Blood Pressure Control. Clin. Sci. 2018, 132, 1383-1401. [CrossRef]

40. Chen, X.; Li, W.; Yoshida, H.; Tsuchida, S.; Nishimura, H.; Takemoto, F.; Okubo, S.; Fogo, A.; Matsusaka, T.; Ichikawa, I. Targeting Deletion of Angiotensin Type 1B Receptor Gene in the Mouse. Am. J. Physiol. 1997, 272, F299-F304. [CrossRef]

41. Oliverio, M.I.; Best, C.F.; Kim, H.S.; Arendshorst, W.J.; Smithies, O.; Coffman, T.M. Angiotensin II Responses in AT1A ReceptorDeficient Mice: A Role for AT1B Receptors in Blood Pressure Regulation. Am. J. Physiol. 1997, 272, F515-F520. [CrossRef] [PubMed]

42. Oliverio, M.I.; Kim, H.S.; Ito, M.; Le, T.; Audoly, L.; Best, C.F.; Hiller, S.; Kluckman, K.; Maeda, N.; Smithies, O.; et al. Reduced Growth, Abnormal Kidney Structure, and Type 2 (AT2) Angiotensin Receptor-Mediated Blood Pressure Regulation in Mice Lacking Both AT1A and AT1B Receptors for Angiotensin II. Proc. Natl. Acad. Sci. USA 1998, 95, 15496-15501. [CrossRef] [PubMed]

43. Gibson, R.E.; Thorpe, H.H.; Cartwright, M.E.; Frank, J.D.; Schorn, T.W.; Bunting, P.B.; Siegl, P.K. Angiotensin II Receptor Subtypes in Renal Cortex of Rats and Rhesus Monkeys. Am. J. Physiol. 1991, 261, F512-F518. [CrossRef] [PubMed]

44. Gröne, H.J.; Simon, M.; Fuchs, E. Autoradiographic Characterization of Angiotensin Receptor Subtypes in Fetal and Adult Human Kidney. Am. J. Physiol. 1992, 262, F326-F331. [CrossRef]

45. Sechi, L.A.; Griffin, C.A.; Grady, E.F.; Kalinyak, J.E.; Schambelan, M. Characterization of Angiotensin II Receptor Subtypes in Rat Heart. Circ. Res. 1992, 71, 1482-1489. [CrossRef]

46. Zhuo, J.; Song, K.; Harris, P.J.; Mendelsohn, F.A. In Vitro Autoradiography Reveals Predominantly AT1 Angiotensin II Receptors in Rat Kidney. Ren. Physiol. Biochem. 1992, 15, 231-239. [CrossRef]

47. Zhuo, J.; Alcorn, D.; Harris, P.J.; Mendelsohn, F.A. Localization and Properties of Angiotensin II Receptors in Rat Kidney. Kidney Int. Suppl. 1993, 42, S40-S46.

48. Zhuo, J.; Dean, R.; MacGregor, D.; Alcorn, D.; Mendelsohn, F.A. Presence of Angiotensin II AT2 Receptor Binding Sites in the Adventitia of Human Kidney Vasculature. Clin. Exp. Pharmacol. Physiol. 1996, 23 (Suppl. 3), S147-S154. [CrossRef]

49. Aguilera, G.; Kapur, S.; Feuillan, P.; Sunar-Akbasak, B.; Bathia, A.J. Developmental Changes in Angiotensin II Receptor Subtypes and AT1 Receptor MRNA in Rat Kidney. Kidney Int. 1994, 46, 973-979. [CrossRef]

50. Gasc, J.M.; Shanmugam, S.; Sibony, M.; Corvol, P. Tissue-Specific Expression of Type 1 Angiotensin II Receptor Subtypes. An in Situ Hybridization Study. Hypertension 1994, 24, 531-537. [CrossRef]

51. Healy, D.P.; Ye, M.Q.; Troyanovskaya, M. Localization of Angiotensin II Type 1 Receptor Subtype MRNA in Rat Kidney. Am. J. Physiol. 1995, 268, F220-F226. [CrossRef] [PubMed]

52. Harrison-Bernard, L.M.; Navar, L.G.; Ho, M.M.; Vinson, G.P.; el-Dahr, S.S. Immunohistochemical Localization of ANG II AT1 Receptor in Adult Rat Kidney Using a Monoclonal Antibody. Am. J. Physiol. 1997, 273, F170-F177. [CrossRef]

53. Mifune, M.; Sasamura, H.; Nakazato, Y.; Yamaji, Y.; Oshima, N.; Saruta, T. Examination of Angiotensin II Type 1 and Type 2 Receptor Expression in Human Kidneys by Immunohistochemistry. Clin. Exp. Hypertens. 2001, 23, 257-266. [CrossRef] [PubMed] 
54. Miyata, N.; Park, F.; Li, X.F.; Cowley, A.W. Distribution of Angiotensin AT1 and AT2 Receptor Subtypes in the Rat Kidney. Am. J. Physiol. 1999, 277, F437-F446. [CrossRef] [PubMed]

55. Li, X.; Hopfer, U.; Zhuo, J. AT1 Receptor-Mediated Uptake of Angiotensin II and NHE-3 Expression in Proximal Tubule Cells through a Microtubule-Dependent Endocytic Pathway. Am. J. Physiol. Ren. Physiol. 2009, 297, F1342-F1352. [CrossRef] [PubMed]

56. Zhuo, J.; Thomas, D.; Harris, P.J.; Skinner, S.L. The Role of Endogenous Angiotensin II in the Regulation of Renal Haemodynamics and Proximal Fluid Reabsorption in the Rat. J. Physiol. 1992, 453, 1-13. [CrossRef]

57. Schrankl, J.; Fuchs, M.; Broeker, K.; Daniel, C.; Kurtz, A.; Wagner, C. Localization of Angiotensin II Type 1 Receptor Gene Expression in Rodent and Human Kidneys. Am. J. Physiol. Ren. Physiol. 2021, 320, F644-F653. [CrossRef]

58. Bouressam, M.-L.; Lartaud, I.; Dupuis, F.; Lecat, S. No Answer to the Lack of Specificity: Mouse Monoclonal Antibody Targeting the Angiotensin II Type 1 Receptor AT1 Fails to Recognize Its Target. Naunyn. Schmiedebergs Arch. Pharmacol. 2018, 391, 883-889. [CrossRef]

59. Elliott, K.J.; Kimura, K.; Eguchi, S. Lack of Specificity of Commercial Antibodies Leads to Misidentification of Angiotensin Type-1 Receptor Protein. Hypertension 2013, 61, e31. [CrossRef]

60. Herrera, M.; Sparks, M.A.; Alfonso-Pecchio, A.R.; Harrison-Bernard, L.M.; Coffman, T.M. Response to Lack of Specificity of Commercial Antibodies Leads to Misidentification of Angiotensin Type-1 Receptor Protein. Hypertension 2013, 61, e32. [CrossRef]

61. He, P.; Yun, C.C. Mechanisms of the Regulation of the Intestinal Exchanger NHE3. J. Biomed. Biotechnol. 2009, 2010, e238080. [CrossRef]

62. Pedersen, S.F.; Counillon, L. The SLC9A-C Mammalian Na+/H+ Exchanger Family: Molecules, Mechanisms, and Physiology. Physiol. Rev. 2019, 99, 2015-2113. [CrossRef] [PubMed]

63. Amemiya, M.; Loffing, J.; Lötscher, M.; Kaissling, B.; Alpern, R.J.; Moe, O.W. Expression of NHE-3 in the Apical Membrane of Rat Renal Proximal Tubule and Thick Ascending Limb. Kidney Int. 1995, 48, 1206-1215. [CrossRef] [PubMed]

64. Biemesderfer, D.; Rutherford, P.A.; Nagy, T.; Pizzonia, J.H.; Abu-Alfa, A.K.; Aronson, P.S. Monoclonal Antibodies for HighResolution Localization of NHE3 in Adult and Neonatal Rat Kidney. Am. J. Physiol. 1997, 273, F289-F299. [CrossRef] [PubMed]

65. Krapf, R.; Solioz, M. Na/H Antiporter MRNA Expression in Single Nephron Segments of Rat Kidney Cortex. J. Clin. Investig. 1991, 88, 783-788. [CrossRef] [PubMed]

66. Zachos, N.C.; Tse, M.; Donowitz, M. Molecular Physiology of Intestinal Na+/H+ Exchange. Annu. Rev. Physiol. 2005, 67, 411-443. [CrossRef]

67. Bobulescu, I.A. Renal Lipid Metabolism and Lipotoxicity. Curr. Opin. Nephrol. Hypertens. 2010, 19, 393-402. [CrossRef]

68. Donowitz, M.; Li, X. Regulatory Binding Partners and Complexes of NHE3. Physiol. Rev. 2007, 87, 825-872. [CrossRef]

69. Li, X.C.; Zheng, X.; Chen, X.; Zhao, C.; Zhu, D.; Zhang, J.; Zhuo, J.L. Genetic and Genomic Evidence for an Important Role of the $\mathrm{Na}+\mathrm{H}+$ Exchanger 3 in Blood Pressure Regulation and Angiotensin II-Induced Hypertension. Physiol. Genom. 2019, 51, 97-108. [CrossRef]

70. Kemp, B.A.; Howell, N.L.; Keller, S.R.; Gildea, J.J.; Shao, W.; Navar, L.G.; Carey, R.M. Defective Renal Angiotensin III and AT2 Receptor Signaling in Prehypertensive Spontaneously Hypertensive Rats. J. Am. Heart Assoc. 2019, 8, e012016. [CrossRef]

71. Li, X.C.; Hopfer, U.; Zhuo, J.L. Novel Signaling Mechanisms of Intracellular Angiotensin II-Induced NHE3 Expression and Activation in Mouse Proximal Tubule Cells. Am. J. Physiol. Ren. Physiol. 2012, 303, F1617-F1628. [CrossRef] [PubMed]

72. Xu, L.; Dixit, M.P.; Nullmeyer, K.D.; Xu, H.; Kiela, P.R.; Lynch, R.M.; Ghishan, F.K. Regulation of Na+/H+ Exchanger-NHE3 by Angiotensin-II in OKP Cells. Biochim. Biophys. Acta 2006, 1758, 519-526. [CrossRef] [PubMed]

73. Pao, A.C.; Bhargava, A.; Di Sole, F.; Quigley, R.; Shao, X.; Wang, J.; Thomas, S.; Zhang, J.; Shi, M.; Funder, J.W.; et al. Expression and Role of Serum and Glucocorticoid-Regulated Kinase 2 in the Regulation of $\mathrm{Na}^{+} / \mathrm{H}^{+}$Exchanger 3 in the Mammalian Kidney. Am. J. Physiol. Ren. Physiol. 2010, 299, F1496-F1506. [CrossRef] [PubMed]

74. Wang, D.; Zhang, H.; Lang, F.; Yun, C.C. Acute Activation of NHE3 by Dexamethasone Correlates with Activation of SGK1 and Requires a Functional Glucocorticoid Receptor. Am. J. Physiol. Cell Physiol. 2007, 292, C396-C404. [CrossRef]

75. Amemiya, M.; Kusano, E.; Muto, S.; Tabei, K.; Ando, Y.; Alpern, R.J.; Asano, Y. Glucagon Acutely Inhibits but Chronically Activates $\mathrm{Na}(+) / \mathrm{H}(+)$ Antiporter 3 Activity in OKP Cells. Exp. Nephrol. 2002, 10, 26-33. [CrossRef]

76. Fuster, D.G.; Bobulescu, I.A.; Zhang, J.; Wade, J.; Moe, O.W. Characterization of the Regulation of Renal Na+/H+ Exchanger NHE3 by Insulin. Am. J. Physiol. Ren. Physiol. 2007, 292, F577-F585. [CrossRef]

77. Bacic, D.; Kaissling, B.; McLeroy, P.; Zou, L.; Baum, M.; Moe, O.W. Dopamine Acutely Decreases Apical Membrane Na/H Exchanger NHE3 Protein in Mouse Renal Proximal Tubule. Kidney Int. 2003, 64, 2133-2141. [CrossRef] [PubMed]

78. Du, Z.; Yan, Q.; Wan, L.; Weinbaum, S.; Weinstein, A.M.; Wang, T. Regulation of Glomerulotubular Balance. I. Impact of Dopamine on Flow-Dependent Transport. Am. J. Physiol. Ren. Physiol. 2012, 303, F386-F395. [CrossRef]

79. Hu, M.C.; Fan, L.; Crowder, L.A.; Karim-Jimenez, Z.; Murer, H.; Moe, O.W. Dopamine Acutely Stimulates Na+/H+ Exchanger (NHE3) Endocytosis via Clathrin-Coated Vesicles: Dependence on Protein Kinase A-Mediated NHE3 Phosphorylation. J. Biol. Chem. 2001, 276, 26906-26915. [CrossRef]

80. Wang, X.; Armando, I.; Upadhyay, K.; Pascua, A.; Jose, P.A. The Regulation of Proximal Tubular Salt Transport in Hypertension: An Update. Curr. Opin. Nephrol. Hypertens. 2009, 18, 412-420. [CrossRef]

81. Lee, D.H.; Riquier, A.D.M.; Yang, L.E.; Leong, P.K.K.; Maunsbach, A.B.; McDonough, A.A. Acute Hypertension Provokes Acute Trafficking of Distal Tubule Na-Cl Cotransporter (NCC) to Subapical Cytoplasmic Vesicles. Am. J. Physiol. Ren. Physiol. 2009, 296, F810-F818. [CrossRef] [PubMed] 
82. McDonough, A.A.; Nguyen, M.T.X. Maintaining Balance Under Pressure: Integrated Regulation of Renal Transporters During Hypertension. Hypertension 2015, 66, 450-455. [CrossRef] [PubMed]

83. Nguyen, M.T.X.; Lee, D.H.; Delpire, E.; McDonough, A.A. Differential Regulation of Na+ Transporters along Nephron during ANG II-Dependent Hypertension: Distal Stimulation Counteracted by Proximal Inhibition. Am. J. Physiol.-Ren. Physiol. 2013, 305, F510-F519. [CrossRef]

84. Li, X.C.; Zhuo, J.L. Recent Updates on the Proximal Tubule Renin-Angiotensin System in Angiotensin II-Dependent Hypertension. Curr. Hypertens. Rep. 2016, 18, 63. [CrossRef]

85. Navar, L.G.; Mitchell, K.D.; Harrison-Bernard, L.M.; Kobori, H.; Nishiyama, A. Intrarenal Angiotensin II Levels in Normal and Hypertensive States. J. Renin-Angiotensin-Aldosterone Syst. JRAAS 2001, 2, S176-S184. [CrossRef]

86. Navar, L.G.; Harrison-Bernard, L.M.; Nishiyama, A.; Kobori, H. Regulation of Intrarenal Angiotensin II in Hypertension. Hypertension 2002, 39, 316-322. [CrossRef]

87. Navar, L.G.; Kobori, H.; Prieto, M.C.; Gonzalez-Villalobos, R.A. Intratubular Renin-Angiotensin System in Hypertension. Hypertension 2011, 57, 355-362. [CrossRef]

88. Li, X.C.; Navar, L.G.; Shao, Y.; Zhuo, J.L. Genetic Deletion of AT1a Receptors Attenuates Intracellular Accumulation of ANG II in the Kidney of AT1a Receptor-Deficient Mice. Am. J. Physiol.-Ren. Physiol. 2007, 293, F586-F593. [CrossRef]

89. Li, X.C.; Zhuo, J.L. Nuclear Factor-KappaB as a Hormonal Intracellular Signaling Molecule: Focus on Angiotensin II-Induced Cardiovascular and Renal Injury. Curr. Opin. Nephrol. Hypertens. 2008, 17, 37-43. [CrossRef]

90. Zou, L.X.; Imig, J.D.; von Thun, A.M.; Hymel, A.; Ono, H.; Navar, L.G. Receptor-Mediated Intrarenal Angiotensin II Augmentation in Angiotensin II-Infused Rats. Hypertension 1996, 28, 669-677. [CrossRef]

91. Kobori, H.; Harrison-Bernard, L.; Navar, L. Enhancement of Angiotensinogen Expression in Angiotensin II-Dependent Hypertension. Hypertension 2001, 37, 1329-1335. [CrossRef] [PubMed]

92. Cogan, M.G. Angiotensin II: A Powerful Controller of Sodium Transport in the Early Proximal Tubule. Hypertension 1990, 15, 451-458. [CrossRef] [PubMed]

93. Harris, P.; Navar, L. Tubular Transport Responses to Angiotensin. Am. J. Physiol 1985, 248, F621-F630. [CrossRef]

94. Harris, P.J.; Young, J.A. Dose-Dependent Stimulation and Inhibition of Proximal Tubular Sodium Reabsorption by Angiotensin II in the Rat Kidney. Pflug. Arch. 1977, 367, 295-297. [CrossRef]

95. Schuster, V.L.; Kokko, J.P.; Jacobson, H.R. Angiotensin II Directly Stimulates Sodium Transport in Rabbit Proximal Convoluted Tubules. J. Clin. Investig. 1984, 73, 507-515. [CrossRef]

96. Crowley, S.D.; Gurley, S.B.; Herrera, M.J.; Ruiz, P.; Griffiths, R.; Kumar, A.P.; Kim, H.-S.; Smithies, O.; Le, T.H.; Coffman, T.M. Angiotensin II Causes Hypertension and Cardiac Hypertrophy through Its Receptors in the Kidney. Proc. Natl. Acad. Sci. USA 2006, 103, 17985-17990. [CrossRef]

97. Li, H.; Weatherford, E.T.; Davis, D.R.; Keen, H.L.; Grobe, J.L.; Daugherty, A.; Cassis, L.A.; Allen, A.M.; Sigmund, C.D. Renal Proximal Tubule Angiotensin AT1A Receptors Regulate Blood Pressure. Am. J. Physiol. -Regul. Integr. Comp. Physiol. 2011, 301, R1067-R1077. [CrossRef]

98. Beale, E.G.; Clouthier, D.E.; Hammer, R.E. Cell-Specific Expression of Cytosolic Phosphoenolpyruvate Carboxykinase in Transgenic Mice. FASEB J. 1992, 6, 3330-3337. [CrossRef]

99. Short, M.K.; Clouthier, D.E.; Schaefer, I.M.; Hammer, R.E.; Magnuson, M.A.; Beale, E.G. Tissue-Specific, Developmental, Hormonal, and Dietary Regulation of Rat Phosphoenolpyruvate Carboxykinase-Human Growth Hormone Fusion Genes in Transgenic Mice. Mol. Cell. Biol. 1992, 12, 1007-1020. [CrossRef]

100. Malstrom, S.E.; Tornavaca, O.; Meseguer, A.; Purchio, A.F.; West, D.B. The Characterization and Hormonal Regulation of Kidney Androgen-Regulated Protein (Kap)-Luciferase Transgenic Mice. Toxicol. Sci. Off. J. Soc. Toxicol. 2004, 79, 266-277. [CrossRef]

101. Meseguer, A.; Catterall, J.F. Cell-Specific Expression of Kidney Androgen-Regulated Protein Messenger RNA Is under Multihormonal Control. Mol. Endocrinol. 1990, 4, 1240-1248. [CrossRef] [PubMed]

102. Rubera, I.; Poujeol, C.; Bertin, G.; Hasseine, L.; Counillon, L.; Poujeol, P.; Tauc, M. Specific Cre/Lox Recombination in the Mouse Proximal Tubule. J. Am. Soc. Nephrol. JASN 2004, 15, 2050-2056. [CrossRef] [PubMed]

103. Wright, E.M. Renal Na(+)-Glucose Cotransporters. Am. J. Physiol. Ren. Physiol. 2001, 280, F10-F18. [CrossRef] [PubMed]

104. Li, X.C.; Shao, Y.; Zhuo, J.L. AT1a Receptor Knockout in Mice Impairs Urine Concentration by Reducing Basal Vasopressin Levels and Its Receptor Signaling Proteins in the Inner Medulla. Kidney Int. 2009, 76, 169-177. [CrossRef] [PubMed]

105. Li, X.C.; Zhuo, J.L. In Vivo Regulation of AT1a Receptor-Mediated Intracellular Uptake of [ ${ }^{125}$ I]Val5-ANG II in the Kidneys and Adrenals of AT1a Receptor-Deficient Mice. Am. J. Physiol. Ren. Physiol. 2008, 294, F293-F302. [CrossRef] [PubMed]

106. Li, X.; Zhuo, J. Proximal Tubule-Dominant Transfer of AT(1a) Receptors Induces Blood Pressure Responses to Intracellular Angiotensin II in AT(1a) Receptor-Deficient Mice. Am. J. Physiol. Regul. Integr. Comp. Physiol. 2013, 304, R588-R598. [CrossRef] [PubMed]

107. Zhuo, J.L.; Kobori, H.; Li, X.C.; Satou, R.; Katsurada, A.; Navar, L.G. Augmentation of Angiotensinogen Expression in the Proximal Tubule by Intracellular Angiotensin II via AT1a/MAPK/NF-KB Signaling Pathways. Am. J. Physiol. Ren. Physiol. 2016, 310, F1103-F1112. [CrossRef]

108. Brown, R.D.; Hilliard, L.M.; Head, G.A.; Jones, E.S.; Widdop, R.E.; Denton, K.M. Sex Differences in the Pressor and Tubuloglomerular Feedback Response to Angiotensin II. Hypertension 2012, 59, 129-135. [CrossRef] 
109. Ji, H.; Zheng, W.; Li, X.; Liu, J.; Wu, X.; Zhang, M.A.; Umans, J.G.; Hay, M.; Speth, R.C.; Dunn, S.E.; et al. Sex-Specific T-Cell Regulation of Angiotensin II-Dependent Hypertension. Hypertension 2014, 64, 573-582. [CrossRef]

110. Veiras, L.C.; McFarlin, B.E.; Ralph, D.L.; Buncha, V.; Prescott, J.; Shirvani, B.S.; McDonough, J.C.; Ha, D.; Giani, J.; Gurley, S.B.; et al. Electrolyte and Transporter Responses to Angiotensin II Induced Hypertension in Female and Male Rats and Mice. Acta Physiol. 2020, 229, e13448. [CrossRef]

111. Venegas-Pont, M.; Sartori-Valinotti, J.C.; Glover, P.H.; Reckelhoff, J.F.; Ryan, M.J. Sexual Dimorphism in the Blood Pressure Response to Angiotensin II in Mice after Angiotensin Converting Enzyme Bloackade. Am. J. Hypertens. 2010, 23, 92-96. [CrossRef] [PubMed]

112. Wolf, E.; Diaz, E.J.; Hollis, A.N.; Hoang, T.A.; Azad, H.A.; Bendt, K.M.; Griffiths, R.C.; Sparks, M.A. Vascular Type 1 Angiotensin Receptors Control Blood Pressure by Augmenting Peripheral Vascular Resistance in Female Mice. Am. J. Physiol.-Ren. Physiol. 2018, 315, F997-F1005. [CrossRef] [PubMed]

113. Xue, B.; Pamidimukkala, J.; Hay, M. Sex Differences in the Development of Angiotensin II-Induced Hypertension in Conscious Mice. Am. J. Physiol. Heart Circ. Physiol. 2005, 288, H2177-H2184. [CrossRef]

114. Clayton, J.A.; Collins, F.S. Policy: NIH to Balance Sex in Cell and Animal Studies. Nature 2014, 509, 282-283. [CrossRef] [PubMed]

115. Galea, L.A.M.; Choleris, E.; Albert, A.Y.K.; McCarthy, M.M.; Sohrabji, F. The Promises and Pitfalls of Sex Difference Research. Front. Neuroendocrinol. 2020, 56, 100817. [CrossRef] [PubMed]

116. Sandberg, K.; Umans, J.G. Recommendations Concerning the New, U.S. National Institutes of Health Initiative to Balance the Sex of Cells and Animals in Preclinical Research. FASEB J. 2015, 29, 1646-1652. [CrossRef] [PubMed]

117. Vallabhajosyula, S.; Ponamgi, S.P.; Shrivastava, S.; Sundaragiri, P.R.; Miller, V.M. Reporting of Sex as a Variable in Cardiovascular Studies Using Cultured Cells: A Systematic Review. FASEB J. 2020, 34, 8778-8786. [CrossRef]

118. Li, J.; Hatano, R.; Xu, S.; Wan, L.; Yang, L.; Weinstein, A.M.; Palmer, L.; Wang, T. Gender Difference in Kidney Electrolyte Transport. I. Role of AT1a Receptor in Thiazide-Sensitive Na+-Cl- Cotransporter Activity and Expression in Male and Female Mice. Am. J. Physiol. Ren. Physiol. 2017, 313, F505-F513. [CrossRef]

119. Tiwari, S.; Li, L.; Riazi, S.; Halagappa, V.K.M.; Ecelbarger, C.M. Sex and Age Result in Differential Regulation of the Renal Thiazide-Sensitive $\mathrm{NaCl}$ Cotransporter and the Epithelial Sodium Channel in Angiotensin II-Infused Mice. Am. J. Nephrol. 2009, 30, 554-562. [CrossRef]

120. Clotet-Freixas, S.; Soler, M.J.; Palau, V.; Anguiano, L.; Gimeno, J.; Konvalinka, A.; Pascual, J.; Riera, M. Sex Dimorphism in ANGII-Mediated Crosstalk between ACE2 and ACE in Diabetic Nephropathy. Lab. Investig. 2018, 98, 1237-1249. [CrossRef]

121. Alsiraj, Y.; Thatcher, S.E.; Charnigo, R.; Chen, K.; Blalock, E.; Daugherty, A.; Cassis, L.A. Female Mice With an XY Sex Chromosome Complement Develop Severe Angiotensin II-Induced Abdominal Aortic Aneurysms. Circulation 2017, 135, 379-391. [CrossRef] [PubMed]

122. Chai, S.Y.; Sexton, P.M.; Allen, A.M.; Figdor, R.; Mendelsohn, F.A. In vitro autoradiographic localization of ANP receptors in rat kidney and adrenal gland. Am. J. Physiol. 1986, 250 Pt 2, F753-F757. [CrossRef] [PubMed]

123. Butlen, D.; Mistaoui, M.; Morel, F. Atrial natriuretic peptide receptors along the rat and rabbit nephrons: $\left[{ }^{125} \mathrm{I}\right]$ alpha-rat atrial natriuretic peptide binding in microdissected glomeruli and tubules. Pflugers Arch. 1987, 408, 356-365. [CrossRef] [PubMed]

124. Brown, J.; Salas, S.P.; Singleton, A.; Polak, J.M.; Dollery, C.T. Autoradiographic localization of atrial natriuretic peptide receptor subtypes in rat kidney. Am. J. Physiol. 1990, 259 Pt 2, F26-F39. [CrossRef]

125. Harris, P.J.; Thomas, D.; Morgan, T.O. Atrial natriuretic peptide inhibits angiotensin-stimulated proximal tubular sodium and water reabsorption. Nature 1987, 326, 697-698. [CrossRef]

126. Zhuo, J.L.; Harris, P.J.; Skinner, S.L. Atrial natriuretic factor modulates proximal glomerulotubular balance in anesthetized rats. Hypertension 1989, 14, 666-673. [CrossRef]

127. McKie, P.M.; Cataliotti, A.; Boerrigter, G.; Chen, H.H.; Sangaralingham, S.J.; Martin, F.L.; Ichiki, T.; Burnett, J.C., Jr. A novel atrial natriuretic peptide based therapeutic in experimental angiotensin II mediated acute hypertension. Hypertension 2010, 56, 1152-1159. [CrossRef]

128. O'Connell, D.P.; Botkin, S.J.; Ramos, S.I.; Sibley, D.R.; Ariano, M.A.; Felder, R.A.; Carey, R.M. Localization of dopamine D1A receptor protein in rat kidneys. Am. J. Physiol. 1995, 268 Pt 2, F1185-F1197. [CrossRef]

129. Zeng, C.; Yang, Z.; Wang, Z.; Jones, J.; Wang, X.; Altea, J.; Mangrum, A.J.; Hopfer, U.; Sibley, D.R.; Eisner, G.M.; et al. Interaction of angiotensin II type 1 and D5 dopamine receptors in renal proximal tubule cells. Hypertension 2005, 45, 804-810. [CrossRef]

130. Gildea, J.J.; Xu, P.; Kemp, B.A.; Carey, R.M.; Jose, P.A.; Felder, R.A. The dopamine $\mathrm{D}_{1}$ receptor and angiotensin II type-2 receptor are required for inhibition of sodium transport through a protein phosphatase 2A pathway. Hypertension 2019, 73, 1258-1265. [CrossRef]

131. Xie, S.; Su, J.; Lu, A.; Lai, Y.; Mo, S.; Pu, M.; Yang, T. Soluble (pro)renin receptor promotes the fibrotic response in renal proximal tubule epithelial cells in vitro via the Akt/ $\beta$-catenin/Snail signaling pathway. Am. J. Physiol. Ren. Physiol. 2020, 319, F941-F953. [CrossRef] [PubMed]

132. Culver, S.A.; Akhtar, S.; Rountree-Jablin, C.; Keller, S.R.; Cathro, H.P.; Gildea, J.J.; Siragy, H.M. Knockout of nephron ATP6AP2 impairs proximal tubule function and prevents high-fat diet-induced obesity in male mice. Endocrinology 2021, 162, bqab200. [CrossRef] [PubMed] 